\title{
Penetapan Tarif pada Reaktivasi Kereta Api Bandung - Ciwidey dengan Metode Ability to Pay (ATP) dan Willingness to Pay (WTP)
}

\author{
HERMAN, REGINAWATI TAMARA
}

Jurusan Teknik Sipil, Institut Teknologi Nasional Bandung

Email: herman@gmail.com

\begin{abstract}
ABSTRAK
Ciwidey adalah kecamatan di Kabupaten Bandung yang merupakan sentra produksi pertanian dan wisata. Pertumbuhan pergerakan orang dan barang dari dan ke daerah ini semakin tinggi. Menindak lanjuti hal ini PT. Kereta Api Indonesia (KAI) berencana mereaktivasi atau menghidupkan kembali jalur kereta api Bandung - Ciwidey. Penelitian ini bertujuan untuk menghitung besarnya tarif kereta api berdasarkan kesediaan dan kemampuan membayar pengguna potensial dengan metode Ability to Pay (ATP) dan Willingness to Pay (WTP). Hasil analisis mendapatkan nilai ATP sebesar Rp9.274,00 dan WTP sebesar Rp17.909,00. Sehingga dapat terlihat bahwa WTP responden lebih besar dari ATP.
\end{abstract}

Kata Kunci: penetapan tarif, reaktivasi kereta api, Ability to Pay (ATP), Willingness to Pay (WTP)

\begin{abstract}
Ciwidey is a district in the Bandung Regency which is a centre agricultural production and tourism. The growth of people and goods movement to and from this area is continuously increase. As a response, PT. Kereta Api Indonesia (KAI) plans to reactivate or revive the Bandung - Ciwidey railroad. This study aims to calculate railway tariffs based on the willingness and ability to pay of the potential users using the Ability to Pay (ATP) and Willingness to Pay (WTP) methods. The result found that ATP is Rp9.274,00 and WTP is Rp17.909,00. Therefore, WTP is higher than the ATP.
\end{abstract}

Keywords: fare determination, railway reactivation, Ability to Pay (ATP), Willingness to Pay (WTP) 


\section{PENDAHULUAN}

Kota Bandung sebagai ibukota provinsi memiliki peran penting dalam pemerintahan dan berperan penting sebagai roda perekonomian dan wisata. Salah satu destinasi wisata di sekitar Kota Bandung adalah Ciwidey yang juga sebagai kota penyangga ekonomi di bidang pertanian. Dengan adanya kegiatan ekonomi, Ciwidey memberikan kontribusi dalam pergerakan regional orang dan barang. Peningkatan pergerakan orang dan barang ini mendorong PT. Kereta Api Indonesia (KAI) untuk mereaktivasi atau menghidupkan kembali jalur kereta api Bandung Ciwidey.

Kegiatan reaktivasi jalur kereta api Bandung - Ciwidey membutuhkan suatu kajian sistematis dari sisi teknis maupun ekonomis. Salah satu kajian penting adalah kajian kelayakan finansial, yang berhubungan dengan tarif yang diberlakukan. Kajian tarif ini dapat ditinjau dari sisi operator dan sisi pengguna. Berdasarkan kebutuhan tersebut, penelitian ini melakukan kajian tarif dari sisi pengguna. Maka, melalui penelitian ini dilakukan perhitungan tarif dengan menggunakan metode Ability to Pay (ATP) dan Willingness to Pay (WTP).

\section{TINJAUAN PUSTAKA}

\subsection{Sistem Transportasi}

Transportasi merupakan pengangkutan manusia atau barang dari satu lokasi ke lokasi lainnya dengan perantara. Sedangkan sistem transportasi sendiri merupakan tatanan keterlibatan antara penumpang atau barang, prasarana dan sarana yang berinteraksi dalam rangkaian pengangkutan penumpang atau barang (Herman, 2019). Secara garis besar transportasi terbagi menjadi 3 (tiga), yaitu transportasi darat, transportasi laut, dan transportasi udara.

\subsection{Transportasi Jalan Rel}

Jalan rel merupakan salah satu prasarana untuk jalur transportasi darat, dimana pengangkutan penumpang atau barang dilakukan di atas kendaraan beroda yang berjalan di atas rel. Rel sendiri adalah pijakan tempat berjalannya roda kereta api. Rel juga berfungsi sebagai media yang meneruskan beban roda ke bantalan.

Pada umumnya, perbedaan antara sarana transportasi kereta api dengan sarana transportasi jalan yaitu kendaraan beroda bergerak di atas permukaan datar sedangkan kereta api bergerak di atas rel pada tempatnya berjalan. Kereta api merupakan moda transportasi berupa kendaraan yang bertenaga gerak di atas jalan rel, serta dapat berjalan sendiri (lokomotif) atau dirangkaikan dengan kendaraan lainnya (gerbong).

Sesuai dengan dimensinya, kereta api sangat efisien untuk mengangkut penumpang dalam jumlah besar serta sesuai untuk moda transportasi massal perkotaan pada koridor yang padat. Selain itu di berbagai perkotaan, kereta api juga digunakan untuk moda transportasi penumpang jarak menengah yang menempuh waktu perjalanan sampai 3 atau 4 jam perjalanan. Penggunaan kereta api juga diterapkan pada moda transportasi barang dengan jumlah yang signifikan. Dengan efektifitas yang tinggi, beberapa negara yang salah satunya adalah Indonesia merencanakan pemanfaatannya terutama sebagai moda transportasi darat, baik untuk perjalanan di dalam kota, antar kota, maupun antar negara.

\subsection{Penetapan Tarif}

Tarif merupakan harga jasa angkutan yang harus dibayar pengguna jasa, baik melalui mekanisme perjanjian sewa menyewa, tawar menawar, maupun ketetapan pemerintah (Warpani, S. P., 2002). Sedangkan tarif jasa sistem transportasi merupakan harga pelayanan 
pengangkutan dari lokasi asal ke lokasi tujuan tertentu yang diatur oleh pihak penyedia jasa sistem transportasi yang berupa moda tertentu kepada pengguna jasa.

Pada prinsipnya penetapan tarif transportasi didasari oleh beberapa hal sebagai berikut:

a. Total biaya untuk menyediakan jasa sistem transportasi.

b. Perilaku pasar dalam menjual jasa sistem transportasi.

c. Kebijakan tarif atau campur tangan pemerintah.

d. Tujuan manajemen perusahaan penyedia jasa sistem transportasi.

e. Pertimbangan tujuan-tujuan sosial kemasyarakatan.

Penetapan tarif transportasi dapat diperhitungan dari beberapa variabel utama dalam sistem pelayanannya. Variabel yang diperhitungan dalam penetapan tarif pada pelayanan angkutan umum antara lain:

a. Pengguna jasa (user), hal-hal yang ditinjau dari aspek pengguna jasa yaitu tarif yang terjangkau oleh para pengguna, mendorong distribusi, dan yang dapat memperluas usaha atau mempermudah melakukan aktifitas dan pekerjaan pengguna sendiri.

b. Penyedia jasa (operator), hal-hal yang ditinjau dari aspek penyedia jasa yaitu besarnya profit atau keuntungan yang diperoleh, modal yang dikeluarkan oleh penyedia jasa, serta efisiensi jasa yang ditawarkan.

c. Pemerintah (regulator), hal-hal yang ditinjau dari aspek pemerintah selaku regulator yaitu menunjang stabilitas ekonomi, pemaksimalan sumber daya dan mobilitas.

Adapun ditetapkannya tarif dimaksudkan untuk memastikan penyelenggaraan transportasi dapat berjalan dengan berkelanjutan dengan juga memastikan kualitas jasa yang sesuai standar keselamatan. Penetapan tarif ini juga diperoleh dengan memperhitungkan daya beli masyarakat dan pengaruhnya terhadap harga produksi.

\subsection{Analisis Statistika}

Pada analisis statistika, distribusi normal memiliki parameter berupa mean dan simpangan baku. Distribusi sampling biasanya didekati dengan distribusi normal. Oleh karena itu, selang (interval) kepercayaan dirancang dalam bentuk estimasi parameter populasi. Sekumpulan dari keseluruhan pengukuran, objek atau individu yang akan diteliti disebut populasi. Sementara itu, bagian dari populasi yang dipelajari dari suatu penelitian disebut sampel. Dalam menentukan berapa jumlah sampel minimum yang dibutuhkan dari suatu populasi, penelitian ini menggunakan Rumus Cochran. Dimana Rumus Cochran dapat digunakan untuk menentukan jumlah sampel atau banyaknya responden pada kondisi dengan data jumlah populasi penelitian yang tidak diketahui secara pasti (Sudarmanto, R. G., 2011).

\subsection{Stated Preference (SP)}

Survei preferensi dapat dilakukan dengan 2 (dua) teknik pendekatan. Teknik pertama merupakan pendekatan Revealed Preference (RP) yang melakukan survei pilihan masyarakat berdasarkan kondisi yang sudah ada atau telah terjadi. Selanjutnya data tersebut dianalisis secara statistik melalui identifikasi faktor-faktor yang mempengaruhi. Kelemahan teknik RP adalah tanggapan individu terhadap kondisi pelayanan yang saat ini belum ada, serta kemungkinan untuk kondisi pelayanan yang akan datang jauh berbeda.

Teknik kedua mencoba menjadi solusi kelemahan pada pendekatan pertama yang disebut pendekatan Stated Preference (SP). SP merupakan survei preferensi tentang suatu alternatif rancangan terbaik yang dibandingkan dengan beberapa macam pilihan alternatif-alternatif rancangan yang lain pada kondisi yang tidak aktual. Hal ini berbeda dengan teknik yang sering dilakukan sebelumnya yaitu RP yang berdasarkan observasi terhadap kondisi aktual. Teknik SP ini telah sering digunakan dalam bidang transportasi karena teknik ini mampu menganalisis 
dan memprediksi bagaimana masyarakat memilih suatu infrastruktur transportasi yang belum ada, atau melihat bagaimana pandangan masyarakat terhadap sesuatu yang baru.

Teknik SP merupakan suatu teknik yang memanfaatkan pernyataan atau pendapat responden secara individu mengenai preferensinya terhadap suatu set preferensi (Fahmi, M., Umyati, U., Riyanto, B. \& Basuki, K. H., 2015).

\subsection{Ability to Pay (ATP)}

ATP merupakan kemampuan membayar seseorang terhadap suatu jasa atau barang berdasarkan persentase pengeluaran dari pendapatan (Basuki, I. \& Chuadinata, S., 2019). Dengan metode household budget, nilai ATP yang didapatkan menggunakan Persamaan 1 berikut:

$$
A T P=\frac{I_{t} \times P_{p} \times P_{t}}{T_{p}}
$$

halmana:

$I_{t} \quad=$ total pendapatan per bulan [Rp/bulan],

$P_{p} \quad=$ persentase pendapatan untuk transportasi per bulan,

$P_{t} \quad=$ persentase untuk angkutan dari pendapatan trasportasi per bulan,

$T_{p} \quad=$ total panjang perjalanan [trip/bulan].

\subsection{Willingness to Pay (WTP)}

WTP merupakan kesediaan pengguna untuk mengeluarkan imbalan atas jasa yang diperolehnya (Basuki, I. \& Chuadinata, S., 2019). Nilai WTP berupa nilai maksimum rupiah yang sanggup dibayarkan oleh responden untuk tarif jasa kereta, yang akan didapatkan menggunakan Persamaan 2 berikut:

$$
M W T P_{\text {tiap jenis pekerjaan }}=\sum_{i=1}^{n} W T P_{i}
$$

halmana:

$M W T P=$ rata-rata nilai WTP,

$n \quad=$ ukuran sampel,

$W T P_{i}=$ nilai WTP maksimum responden ke- $i$.

\subsection{Hubungan ATP dan WTP}

Dalam pelaksanaan untuk menentukan tarif sering terjadi benturan antara besarnya WTP dan ATP (Fitriyani, H., 2016) sebagai berikut:

1. ATP > WTP

Kondisi ATP lebih besar dari WTP ini dapat terjadi jika pelaku perjalanan memiliki penghasilan yang relatif tinggi sedangkan utilitas terhadap jasa tersebut relatif rendah. Maka, pelaku perjalanan pada kondisi ini disebut choice riders.

2. $\quad$ ATP $=$ WTP

Kondisi ATP sama dengan WTP menunjukan bahwa terjadi keseimbangan utilitas pelaku perjalanan dengan biaya yang dikeluarkan untuk membayar jasa tersebut.

3. ATP $<$ WTP

Kondisi ini berkebalikan pada kondisi di poin pertama, dimana ATP lebih kecil dari WTP. $\mathrm{Hal}$ ini kemungkinan dapat terjadi jika pelaku perjalanan memiliki penghasilan yang relatif rendah sedangkan utilitas terhadap jasa tersebut sangat tinggi. Maka, preferensi pelaku perjalanan lebih dipengaruhi oleh utilitas. 


\subsection{Penelitian Terdahulu}

Beberapa penelitian terkait yang berkaitan dengan ATP dan WTP untuk angkutan umum menghasilkan nilai ATP lebih besar dari nilai WTP pengguna kereta api Bandara Soekarno Hatta - Manggarai (Permata, M. R., 2012), tarif angkutan Batik Solo Trans lebih besar dari ATP dan WTP pengguna (Lestari, M. W., 2016), dan penetapan tarif yang layak pada Kereta Api Sancaka setelah dilakukan perbaikan pelayanan usulan penumpang (Prajawan, D. O., 2013).

\section{METODOLOGI PENELITIAN}

Penelitian dilakukan dengan melakukan wawancara kuisioner kepada para responden. Penyebaran kuesioner dilakukan terhadap jumlah sampel yang sudah ditentukan. Selanjutnya dilakukan pengolahan data berupa karakteristik responden, ATP dan WTP.

Kuesioner terbagi menjadi tiga bagian. Bagian pertama dirancang untuk mengetahui karakteristik calon penumpang Kereta Api Bandung - Ciwidey dengan menanyakan umur, jenis kelamin, frekuensi perjalanan ke Ciwidey, alat transportasi yang sering digunakan, waktu tempuh menuju Ciwidey, posisi tempat tinggal, maksud perjalanan, dan biaya satu kali perjalanan ke Ciwidey.

Bagian kedua merupakan, kuesioner ATP yang merupakan kemampuan membayar dari masyarakat terhadap suatu barang atau jasa. Faktor-faktor ATP yang digunakan dalam kuesioner antara lain total pendapatan responden, alokasi pendapatan terhadap transportasi, dan alokasi biaya transortasi Bandung - Ciwidey per bulan.

Kuesioner WTP merupakan bagian terakhir dari kuesioner yang kerupakan ketersediaan penumpang untuk mengeluarkan besaran rupiah sebagai pembayaran suatu pelayanan kereta api yang dinikmatinya. Dalam melakukan perhitungan WTP, responden ditanyakan preferensi tarif kereta api yang di harapkan. Adapun dalam pembentukan kuesioner ini metode SP digunakan. Variabel yang digunakan untuk membentuk beberapa skenario SP adalah tarif kereta api.

Berdasarkan hasil pengolahan data dan analisis dapat diketahui nilai tarif responden berdasarkan ATP dan WTP.

\section{ANALISIS DAN PEMBAHASAN}

\subsection{Penentuan Ukuran Sampel}

Pada penyebaran kuesioner Kereta Api Bandung - Ciwidey ini menggunakan Rumus Cochran. Dengan tingkat kepercayaan yang digunakan 95\% (menghasilkan $z=1,96$ ) dengan nilai tingkat kesalahan/taraf kekeliruan yang digunakan sebesar $10 \%$, sehingga diperoleh ukuran sampel minimum yang akan diteliti sebanyak 100 responden.

\subsection{Perancangan dan Penyebaran Kuesioner}

Kuesioner dirancang dengan terbagi menjadi (3) tiga bagian, yaitu kuesioner karakteristik responden yang bertujuan untuk mengetahui gambaran identitas responden berupa jenis kelamin, usia, pekerjaan, tujuan perjalanan, frekuensi melakukan perjalanan, serta maksud/tujuan perjalanan yang sering dilakukan. Berkaitan dengan ATP berisi tentang pendapatan, alokasi pendapatan terhadap transportasi, dan alokasi pendapatan untuk perjalanan Bandung - Ciwidey. Berkaitan dengan WTP berisi tarif yang diharapkan responden disandingkan dengan waktu perjalanan jika menggunakan kereta api. 


\subsection{Analisis Karakteristik Responden}

Karakteristik responden hasil wawancara kuesioner adalah sebagai berikut:

a. Jenis kelamin adalah $58 \%$ laki-laki dan $42 \%$ perempuan.

b. Usia adalah $24 \%$ di bawah usia 20 tahun, $69 \%$ antara usia $20-40$ tahun, dan $7 \%$ antara usia 40 - 60 tahun.

C. Pekerjaan adalah $20 \%$ petani, $18 \%$ pelajar dan mahasiswa, $13 \%$ PNS, $4 \%$ pegawai BUMN/BUMD, dan 45\% karyawan pabrik, kuli bangunan, ibu rumah tangga, peternak, dan wiraswasta.

d. Frekuensi perjalanan per minggu adalah 53\% $1-2$ kali, 33\% $3-4$ kali, $11 \% 5-6$ kali, dan 3\% $7-8$ kali.

e. Tujuan perjalanan adalah $45 \%$ kerja, $18 \%$ sekolah, $7 \%$ liburan, dan $30 \%$ lainnya.

f. Pendapatan adalah 75\% kurang dari Rp3.000.000,00; 25\% antara Rp3.000.000,00 Rp5.000.000,00.

\subsection{Analisis Ability to Pay (ATP)}

Pada analisis ATP calon pengguna Kereta Api Bandung - Ciwidey, besaran nilai ATP dibuat dengan mempertimbangkan pendapatan responden, alokasi pendapatan terhadap transportasi, alokasi biaya transportasi dari Bandung ke Ciwidey per bulan, dan frekuensi perjalanan Bandung - Ciwidey per bulan. Adapun berdasarkan data yang didapatkan, pendapatan responden paling banyak yaitu < Rp3.000.000,00 sebesar 75\%, kemudian sebesar 25\% antara Rp3.000.000,00 - Rp5.000.000,00. Hasil ini dideskripsikan pada Gambar 1.

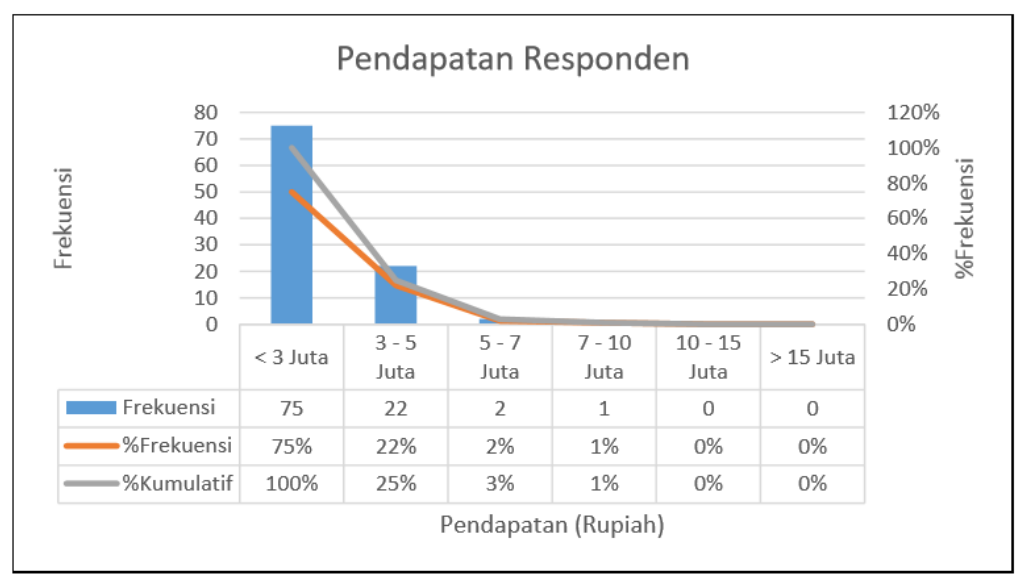

Gambar 1. Diagram pendapatan responden

ATP yang dilakukan pada penelitian ini menggunakan tabel perhitungan yang dapat dilihat pada Tabel 1. ATP minimum responden Rp5.000,00 dan maksimum sebesar Rp25.000,00. Range ATP responden yang terbesar terdapat pada range Rp11.000,00 - Rp15.000,00 yaitu $53 \%$ dan $23 \%$ pada range Rp5.000,00 - Rp10.000,00 dan rata-rata nilai ATP responden adalah sebesar Rp14.677,00. Seperti diperlihatkan pada Gambar 2. 
Tabel 1. Perhitungan Ability to Pay (ATP)

\begin{tabular}{|c|c|c|c|c|c|c|c|}
\hline Responden & $\begin{array}{c}\text { Rata-rata } \\
\text { pendapatan } \\
\text { per bulan }\end{array}$ & $\begin{array}{l}\text { Rata-rata } \\
\text { alokasi } \\
\text { biaya } \\
\text { transportasi }\end{array}$ & $\begin{array}{c}\text { \%Rata-rata } \\
\text { alokasi } \\
\text { biaya } \\
\text { transportasi }\end{array}$ & $\begin{array}{l}\text { Rata-rata } \\
\text { alokasi } \\
\text { biaya } \\
\text { transportasi } \\
\text { Bandung - } \\
\text { Ciwidey }\end{array}$ & $\begin{array}{l}\text { \%Rata-rata } \\
\text { alokasi } \\
\text { biaya } \\
\text { transportasi } \\
\text { Bandung - } \\
\text { Ciwidey }\end{array}$ & $\begin{array}{l}\text { Frekuensi } \\
\text { Perjalanan }\end{array}$ & $\begin{array}{c}\text { ATP } \\
\text { Responden }\end{array}$ \\
\hline & A & B & $C=(B / A) * 100 \%$ & D & $E=(D / A) * 100 \%$ & $\mathbf{F}$ & $\begin{array}{c}\mathbf{G}= \\
\left(A^{*} C * E\right) /\left(F^{*} 2\right)\end{array}$ \\
\hline 1 & $7-10$ juta & 1.000 .000 & 0,100 & 50.000 & 0,050 & 1 & 25.000 \\
\hline 2 & $<3$ juta & 100.000 & 0,033 & 30.000 & 0,300 & 1 & 15.000 \\
\hline$\ldots$ & $\ldots \ldots$ & $\ldots \ldots$ & $\ldots \ldots$ & $\ldots \ldots$ & $\ldots \ldots$ & $\ldots \ldots$ & $\ldots \ldots$ \\
\hline$\ldots$ & $\ldots \ldots$ & $\ldots \ldots$ & $\ldots \ldots$ & $\ldots \ldots$ & $\ldots \ldots$ & $\ldots \ldots$ & $\ldots \ldots$ \\
\hline 100 & $<3$ juta & 200.000 & 0,067 & 40.000 & 0,200 & 1 & 20.000 \\
\hline
\end{tabular}

Analisis ATP diperoleh 23\% responden memilki ATP antara Rp5.000,00 - Rp10.000,00; 53\% responden memiliki ATP antara Rp11.000 - Rp15.000,00; 18\% responden memiliki ATP antara Rp16.000,00 - Rp20.000,00; dan 6\% responden memiliki ATP > Rp20.000,00. Selanjutnya dianalisis berdasarkan distribusi normal yang diperlihatkan pada Gambar 3.

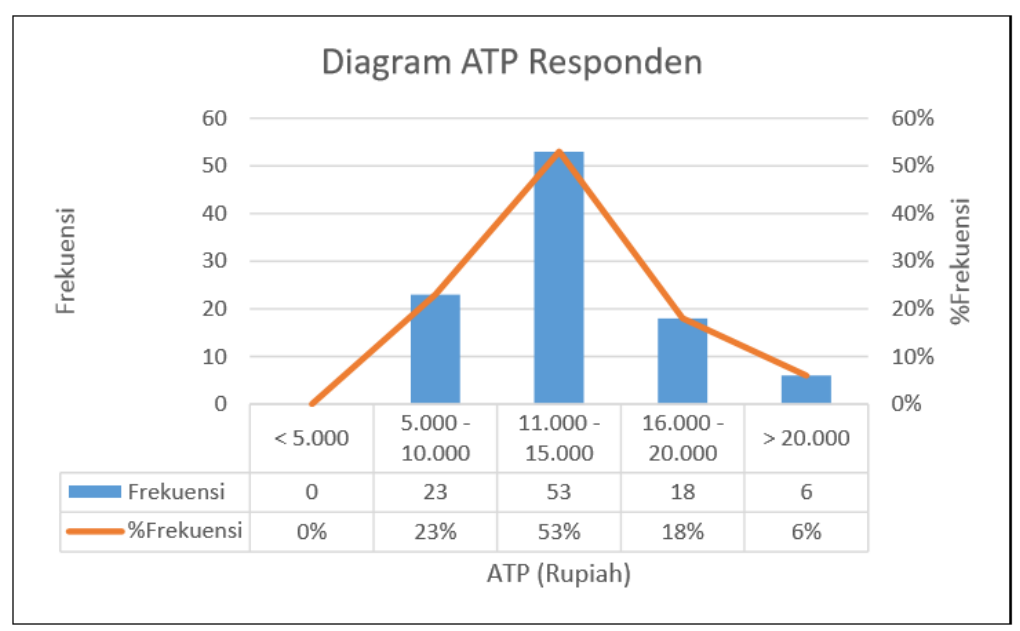

Gambar 2. Diagram ATP responden

Perhitungan dengan menggunakan distribusi normal diperoleh ATP 90\% sebesar Rp9.274,00; dan ATP 10\% sebesar Rp20.081,00. Dimana hal itu menunjukkan jika tarif yang ditetapkan sebesar Rp9.274,00 maka sebanyak 90\% dari responden mampu membayar tarif tersebut. Jika tarif yang ditetapkan sebesar Rp20.081,00 maka hanya $10 \%$ dari responden yang mampu membayar tarif tersebut. Namun jika dilihat dari nilai rata-rata ATP responden yaitu sebesar Rp14.677,00; hal ini menunjukkan hanya ada $50 \%$ atau sebagian dari responden yang mampu membayar dengan tarif tersebut. 


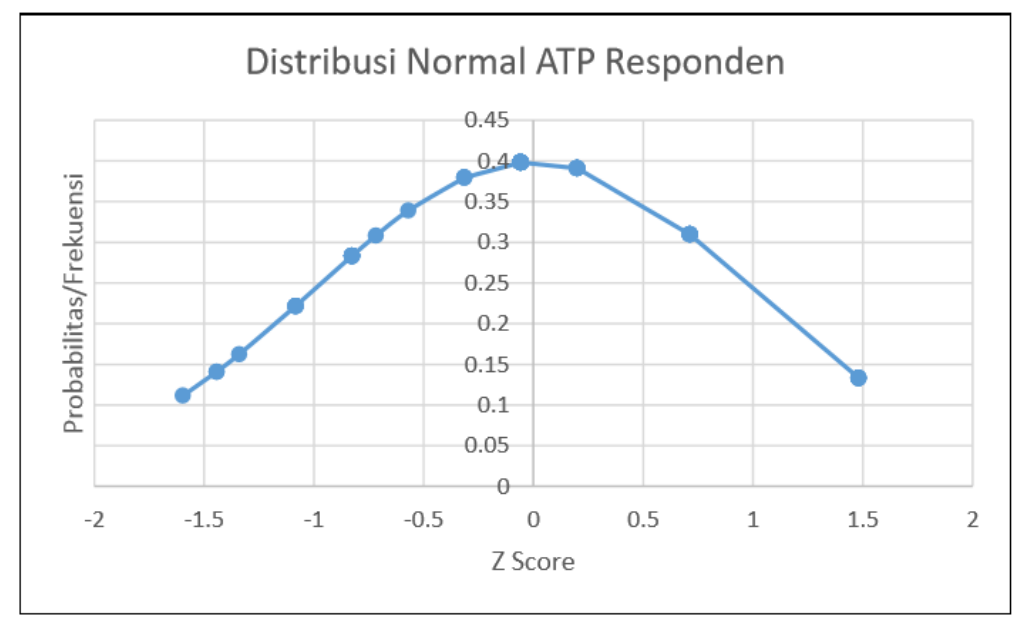

Gambar 3. Grafik distribusi normal ATP responden

\subsection{Analisis Willingness to Pay (WTP)}

Analisis WTP pada penelitian ini menggunakan metode stated preference, dimana para responden diberikan beberapa alternatif pilihan tarif kereta api dimana responden diminta memilih tarif yang mereka inginkan berdasarkan pilihan yang disediakan dengan waktu perjalanan kereta yang berbeda-beda. Hasil ini diperlihatkan pada Gambar 4.

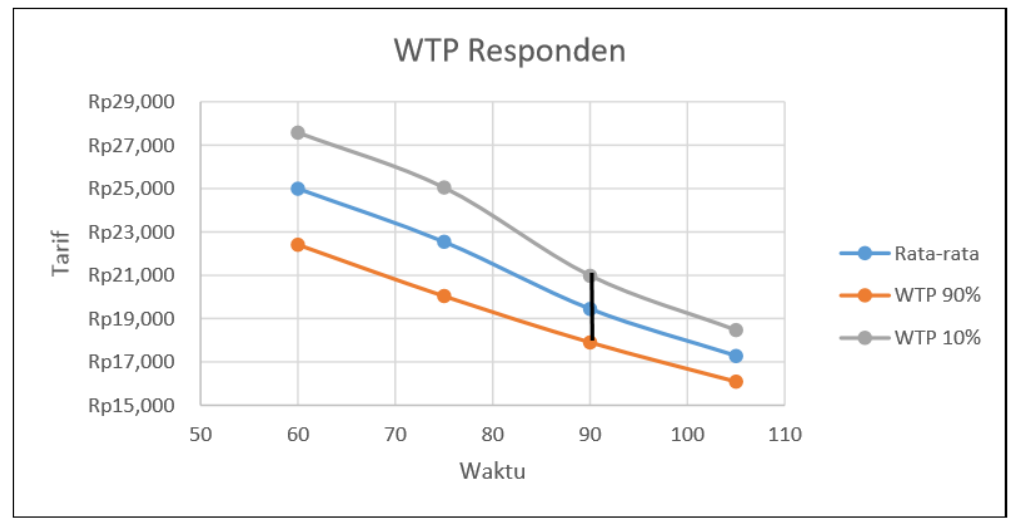

Gambar 4. Diagram WTP terhadap waktu

Seperti yang terlihat pada Gambar 4 terdapat tiga garis yang menunjukkan nilai tarif terhadap waktu. Garis biru menggambarkan rata-rata tarif, dimana pada saat nilai tarif mencapai ratarata yang menunjukkan $50 \%$ dari responden yang berminat menggunakan kereta api. Sedangkan garis berwarna abu-abu menunjukkan hanya $10 \%$ dari responden yang berminat menggunakan kereta api, dimana pada saat waktu perjalanan kereta api 105 menit dengan tarif sebesar Rp18.472,00; saat waktu perjalanan kereta api 90 menit dengan tarif sebesar Rp20.998,00; saat waktu perjalanan 75 menit dengan tarif sebesar Rp25.054,00; dan saat waktu perjalanan 60 menit dengan tarif sebesar Rp27.587,00.

Sedangkan untuk garis merah menunjukkan $90 \%$ dari responden berminat untuk menggunakan kereta api, dimana $90 \%$ responden berminat menggunakan kereta api pada saat waktu perjalanan kereta api 105 menit dengan tarif sebesar Rp16.099,00; saat waktu perjalanan kereta api 90 menit dengan tarif sebesar Rp17.909,00; saat waktu perjalanan 75 menit dengan tarif sebesar Rp20.043,00; dan saat waktu perjalanan 60 menit dengan tarif sebesar Rp22.413,00. 
Berdasarkan informasi dari Humas PT.KAI (Persero) mengatakan menurut hasil simulasi diperkirakan Kereta Api Bandung - Ciwidey akan memerlukan waktu kurang lebih 1,5 jam (90 menit) untuk satu kali perjalanan. Hasil analisis WTP adalah diperoleh nilai WTP sebesar Rp19.448,00 yang menunjukkan $50 \%$ dari responden akan menggunakan kereta dengan tarif tersebut, sedangkan untuk $90 \%$ dari responden akan menggunakan kereta dengan tarif Rp17.909,00 dan 10\% dari responden yang akan menggunakan kereta api jika tarifnya sebesar Rp20.998,00.

Hasil analisis menunjukkan nilai WTP rata-rata responden untuk Kereta Api Bandung - Ciwidey dengan asumsi waktu perjalanan 105 menit adalah sebesar Rp17.286,00; nilai WTP rata-rata dengan asumsi waktu perjalanan 90 menit adalah sebesar Rp19.448,00; nilai WTP rata-rata dengan asumsi waktu perjalanan 75 menit adalah sebesar Rp22.548,00; dan nilai WTP ratarata dengan asumsi waktu perjalanan 60 menit adalah sebear Rp25.000,00.

\subsection{Pembahasan}

Berdasarkan hasil perhitungan ATP dan WTP dapat direkapitulasi nilai ATP dan WTP diperlihatkan pada Gambar 5.

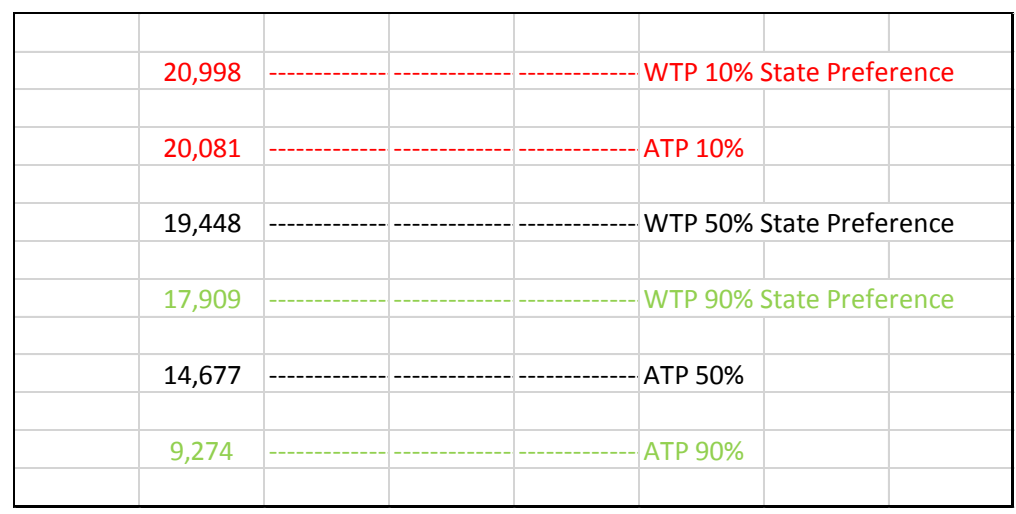

Gambar 5. Grafik nilai ATP - WTP

Beberapa hal yang bisa dibahas hasil perhitungan tersebut adalah:

a. Nilai WTP lebih besar dari nilai ATP, artinya responden memiliki keinginan membayar lebih besar kemampuannya. Waktu perjalanan selama 90 menit dari Bandung ke Ciwidey atau sebaliknya dinilai oleh responden lebih diharapkan. Kemampuan responden lebih rendah dari keinginan untuk membayar.

b. Semakin besar persentase responden yang menggunakan kereta api semakin besar juga perbedaan antara kemampuan dan keinginan membayar responden. Ini menunjukkan bahwa responden pengguna kereta api memiliki tingkat kemampuan yang semakin rendah seiring dengan bertambahnya persentase pengguna kereta api.

c. PT KAI harus mempertimbangkan hal-hal yang telah disebutkan di atas dalam penetapan skema tarif kereta api Bandung - Ciwidey dan jumlah penumpang yang menggunakan kereta api tersebut.

\section{KESIMPULAN DAN SARAN}

\subsection{Kesimpulan}

Beberapa kesimpulan dari penelitian ini adalah:

1. Nilai ATP adalah Rp20.081,00 dan WTP adalah Rp20.998,00 pada $10 \%$ responden menggunakan kereta api.

2. Nilai ATP adalah Rp14.677,00 dan WTP adalah Rp19.448,00 pada 50\% responden menggunakan kereta api. 
3. Nilai ATP adalah Rp9.274,00 dan WTP adalah Rp17.909,00 pada $90 \%$ responden menggunakan kereta api.

4. Nilai ATP lebih kecil dari nilai WTP.

5. Semakin besar tingkat pengguna kereta api semakin besar perbedaan antara ATP dan WTP.

\subsection{Saran}

PT KAI mempertimbangkan nilai ATP lebih kecil dari nilai WTP dan perbedaan yang semakin besar nilai antara ATP dan WTP dalam penetapan tarif kereta api Bandung - Ciwidey.

\section{DAFTAR RUJUKAN}

Basuki, I. \& Chuadinata, S. (2019). Analisis Ability to Pay and Willingness to Pay Jasa Kereta Api Yogyakarta International Airport. Jurnal Spektran, 72), 140-146.

Fahmi, M., Umyati, U., Riyanto, B. \& Basuki, K. H. (2015). Pemodelan Pemilihan Moda dengan Metode Stated Preference, Studi Kasus Perpindahan dari Sepeda Motor ke BRT Rute Semarang - Kendal. Jurnal Karya Teknik Sipil, 4(4), 343-352.

Fitriyani, H. (2016). Pengaruh WTP (Willingness to Pay) dan ATP (Ability to Pay) terhadap Keputusan Penggunaan Tarif Angkutan pada Jasa Transportasi Hiba Utama (Studi Kasus Bus Hiba Utama Depok - Bandara Soekarno Hatta). Tugas Akhir. Depok: Jurusan Manajemen - Universitas Gunadarma.

Herman. (2019). Sistem Transportasi. Bandung: Institut Teknologi Nasional Bandung.

Lestari, M. W. (2016). Analisis Kelayakan Tarif Batik Solo Trans (BST) Ditinjau dari Ability to Pay (ATP) dan Willingness to Pay (WTP). Skripsi. Surakarta: Program Studi Teknik Sipil - Universitas Muhammadiyah Surakarta.

Permata, M. R. (2012). Analisa Ability to Pay dan Willingness to Pay Pengguna Jasa Kereta Api Bandara Soekarno Hatta - Mannggarai. Tesis. Depok: Program Studi Teknik Sipil Univesitas Indonesia.

Prajawan, D. O. (2013). Evaluasi Penetapan Tarif Kereta Api Sancaka (Studi Kasus: Kereta Api Sancaka Jurusan Yogyakarta). Skripsi. Surakarta: Program Studi Teknik Sipil Universitas Muhammadiyah Surakarta.

Sudarmanto, R. G. (2011). Penentuan Besarnya Sampel Penelitian Menggunakan Rumus Cochran. Lampung: Universitas Lampung.

Warpani, S. P. (2002). Pengelolaan Lalu Lintas dan Angkutan Jalan. Bandung: ITB. 